\title{
IMPLEMENTATION OF PROFFESIONAL PHARMACEUTICAL COUNSELLING SCHEME IN COMMUNITY PHARMACIES IN POZNAN AND WARSAW (POLAND)
}

\author{
MAGDALENA WASZYK-NOWACZYK ${ }^{1 *}$, BEATA SZUKALSKA ${ }^{2}$, WERONIKA GUZENDA $^{3}$, \\ MICHAŁ MICHALAK ${ }^{4}$
}

${ }^{I}$ Department of Pharmaceutical Technology, Pharmacy Practice Division, Poznan University of Medcial Sciences, 70 Bukowska Street, 60-812 Poznan, Poland

${ }^{2}$ Medicover Pharmacy, 88 Baraniaka Street, 61-131 Poznan, Poland

${ }^{3}$ Student's Pharmaceutical Care Group, Department of Pharmaceutical Technology, Pharmacy Practice Division, Poznan University of Medical Sciences, 70 Bukowska Street, 60-812 Poznan, Poland

${ }^{4}$ Department of Computer Science and Statistics, Poznan University of Medical Sciences, 79 Dabrowskiego Street, 60-529

Poznan, Poland

*corresponding author: mwaszyk@ump.edu.pl

\begin{abstract}
Although pharmaceutical care implementation in Poland isn't completed, patients often seek for simply counselling. For that reason, pharmacists and pharmacy technicians should be prepared to give professional advices. The purpose of the study was to implement and assume the pharmaceutical counselling scheme in community pharmacy. After scheme implementation an anonymous questionnaire was administered to 245 pharmacy employees in Poznan and Warsaw, Poland. In this study patients' preferred more often pharmacist consultation $(\mathrm{p}<0.001)$. Pharmacists confirmed that patients' diagnosis were correct and they were more critical with this opinion $(\mathrm{p}=0.047)$. Pharmacists more often referred patients' for physician consultation and assessed that there were contraindications to prescribed drugs (respectively $\mathrm{p}=0.013$ and $\mathrm{p}=0.005$ ). Development of pharmaceutical counselling in Polish community pharmacy may help to increase safety of pharmacotherapy and gives a possibility to cooperate with a patient and physician in a better way.
\end{abstract}

\section{Rezumat}

Deși implementarea serviciilor de îngrijire farmaceutică în Polonia nu este finalizată, pacienții adesea solicită consiliere. Din acest motiv, farmaciștii şi asistenții de farmacie ar trebui să fie pregătiţi să ofere sfaturi profesionale. Scopul studiului a fost implementarea și asumarea schemei de consiliere în farmacia comunitară. După implementarea schemei, a fost trimis un chestionar anonim la 245 de farmaciști și asistenți de farmacie din Poznan și Varșovia, Polonia. În acest studiu, pacienții au preferat mai des consilierea farmacistului $(p<0,001)$, iar acesta a stabilit existența unor contraindicaţii la medicamentele prescrise $(p=0,013$ și, respectiv, $p=0,005)$. Dezvoltarea consilierii farmaceutice în farmacia comunitară din Polonia poate contribui la creșterea siguranței farmacoterapiei și oferă posibilitatea cooperării optime a farmacistului cu pacienții și medicii.

Keywords: pharmacist, pharmacy technician, pharmaceutical counselling

\section{Introduction}

Community pharmacy is a place where health professionals are very accessible to the public. Pharmacy employees like pharmacists or technicians can provide professional counselling services (PCS) for their patients. This is very important in Poland where pharmaceutical care (PC) implementation is very problematic, especially because the legislation is not very specific on this subject uncompleted law [13, 18]. Many publications are focused on pharmacists' role in chronic diseases treatment or prevention and in avoiding drug problems related to polypragmasy $[2,8$, $15,16]$. Australian surveys conducted with community pharmacists allowed to identify one of the major problems with providing that kind of services which is the lack of integration within the health system [11]. Polish Pharmaceutical Society in a document from 2015 constituted a plan of developing pharmaceutical practice including PC and initiatives in favour of reinforcing the role of pharmacists in Polish National Health System. This process is predicted to be completed in the year 2030 in Poland [10]. Meanwhile, pharmacists have to try to do as much as possible to help their patients understand the therapy prescribed by physicians and first of all to contribute to the self-treatment with over the counter (OTC) medicines. As one of the studies in Slovenia showed, patients are generally familiar with information about proper administration of medications, but they know little about medication safety [5]. Moreover, people often seek for pharmaceutical advice when they have smaller 
health issues, because of the professionalism and accessibility of PCS in community pharmacies according to Tucker and Stewart [14].

As evident from the general trends, it is essential and appropriate to implement professional PCS also in Polish community pharmacy. There is no research data in Poland in this area therefore this is an innovative topic. The aim of the study was to implement and assume the pharmaceutical counselling scheme in community pharmacies to confirm benefits for the patients.

\section{Materials and Methods}

The research was conducted between May and November 2017. The study group included pharmacists, pharmacy technicians and patients from community pharmacies in Poland. All pharmacies were located in the close neighbourhood to private medical centres' in Warsaw and Poznan, which are classified as the biggest cities in Poland in regard to the number of citizens and area.

Professional pharmacy employees completed training courses and were closely acquainted with the study. The main establishment of the project was to create a standard of PCS in which every dialog between pharmacy employees and patient ends with the counselling advice which was adjusted to the situation and patient needs according to essential knowledge about health condition or administered medicines.

An anonymous questionnaire was developed by the authors of the study to assess pharmacy employees' attitude towards patients during PCS. It consisted of open and close questions which concerned information about pharmacy employees, patients, and scheme of counselling in two cases: self-treatment or after physician consultation. Answers given by pharmacists and pharmacy technicians were compared in order to identify if there are any relevant differences between these two groups considering PCS. The study was approved by the ethics review board at Poznan University of Medical Sciences, Poland.

Statistical analysis

Statistica PL 10 (StatSoft) package was used to perform the statistical analysis. The correlations between analysed nominal data was performed by Chi-square test of independence $\left(\chi^{2}\right)$. All statistical analyses were considered significant at $\mathrm{p}<0.05$.

\section{Results and Discussion}

The questionnaire was completed by 245 professional pharmacy employees (241 women, 4 men): 146 pharmacists (143 women, 3 men) and 99 pharmacy technicians (98 women, 1 man). In this study there were also involved 245 patients (172 women, 73 men). In the Poznan, 45 pharmacy employees and 45 patients were included, and in Warsaw 200 pharmacy employees and 200 patients. Most professional pharmacy employees were 41 - 50 years old $(52.2 \%)$ and 24 - 30 years old $(40.0 \%)$ and 103 of patients were under 30 years old $(42.0 \%)$ and 81 of them were between 31 - 40 years old (33.1\%). Characteristics of the study participants are presented in Table I. In the conducted study, $20.0 \%$ of patients were taking the drugs for other persons (e.g. for child, mother, father) and $80.0 \%$ for themselves. In pharmacists' opinion main patients' problems were connected with cold (22.9\%), pain (16.7\%) and allergy (9.8\%) (Figure 1). $45.7 \%$ of patients' were taking POM (prescription only medicines) and $37.1 \%$ of them OTC (over the counter) medicines (Figure 2) and men more often than women purchased this products $(\mathrm{p}=0.004$, $24.3 \% \pm 6.5 \%$ vs $42.7 \% \pm 11.2 \%$ Figure 3 ).

Table I

Characteristics of the study participants

\begin{tabular}{|c|c|c|c|c|}
\hline & \multicolumn{3}{|c|}{$\begin{array}{c}\text { Professional pharmacy employees } \\
\mathrm{n}(\%)\end{array}$} & \multirow{2}{*}{$\begin{array}{c}\begin{array}{c}\text { Patients } \\
\text { n }(\%)\end{array} \\
\text { Total } \\
245(100)\end{array}$} \\
\hline & $\begin{array}{l}\text { Pharmacists } \\
146(59.6)\end{array}$ & $\begin{array}{c}\text { Pharmacy technicians } \\
99(40.4)\end{array}$ & $\begin{array}{c}\text { Total } \\
245(100)\end{array}$ & \\
\hline \multicolumn{5}{|l|}{ Gender } \\
\hline Male & $3(2.1)$ & $1(1.0)$ & 4 (1.6) & 73 (29.8) \\
\hline Female & $143(97.9)$ & $98(99.0)$ & $241(98.4)$ & $172(70.2)$ \\
\hline \multicolumn{5}{|l|}{ City } \\
\hline Poznan & $21(14.4)$ & $24(24.2)$ & $45(18.4)$ & $45(18.4)$ \\
\hline Warsaw & $125(85.6)$ & $75(75.8)$ & $200(81.6)$ & $200(81.6)$ \\
\hline \multicolumn{5}{|l|}{ Age [years] } \\
\hline $24-30$ & $65(44.5)$ & $33(33.3)$ & $98(40.0)$ & $103(42.0)$ \\
\hline $31-40$ & $15(10.3)$ & $3(3.0)$ & $18(7.4)$ & $81(33.1)$ \\
\hline $41-50$ & $65(44.5)$ & $63(63.7)$ & $128(52.2)$ & $27(11.0)$ \\
\hline$>50$ & $1(0.7)$ & $0(0.0)$ & $1(0.4)$ & 34 (13.9) \\
\hline
\end{tabular}




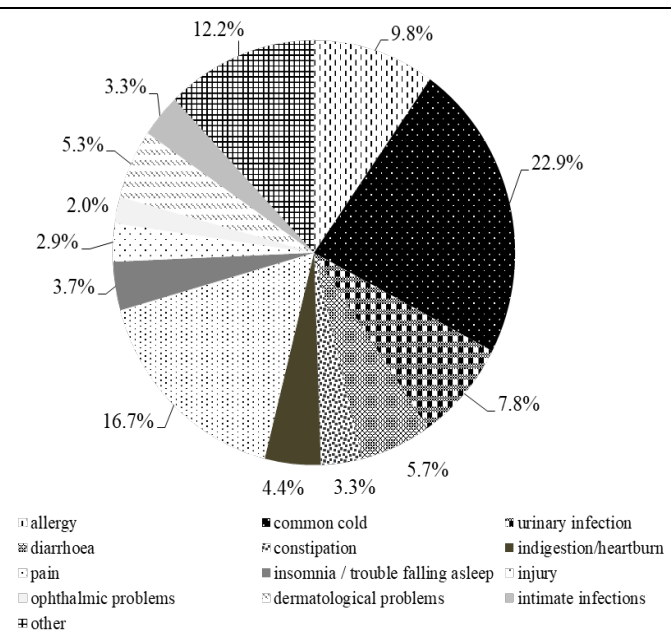

Figure 1.

The main patients' problems during pharmacists' counselling $(n=270)$

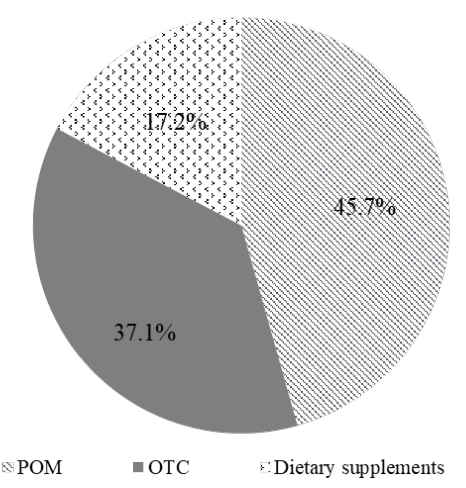

Figure 2.

Types of products used by patients $(\mathrm{n}=197)$, where $\mathrm{POM}=$ prescription only medicines, $\mathrm{OTC}=$ over the counter

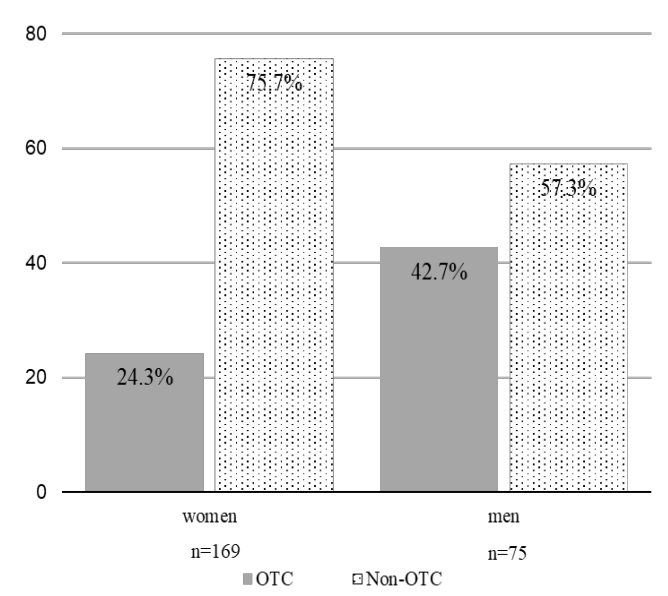

Figure 3.

The effect of gender on purchasing products in community pharmacy $(n=244 ; p=0.004)$

$59.2 \%$ of patients were subjects of auto-medication and $40.8 \%$ had a prescribed medical treatment by the physician. Patients' preferred more often pharmacist consultation rather than pharmacy technicians both in self-treatment and after physician consultation (respectively $\mathrm{p}<0.001,27.6 \% \pm 9.4 \%$ vs $3.5 \% \pm$ $4.8 \%$, Figure $4 ; \mathrm{p}<0.001,26.7 \% \pm 11.2 \%$ vs $0.0 \%$ $\pm 0.0 \%$, Figure 5). $93.1 \%$ of pharmacists confirmed that patients' diagnosis were correct (Figure 6) and pharmacists were more critical than pharmacy technicians towards this opinion $(\mathrm{p}=0.047,89.7 \% \pm$ $6.4 \%$ vs $98.3 \% \pm 3.4 \%$; Figure 7 ).

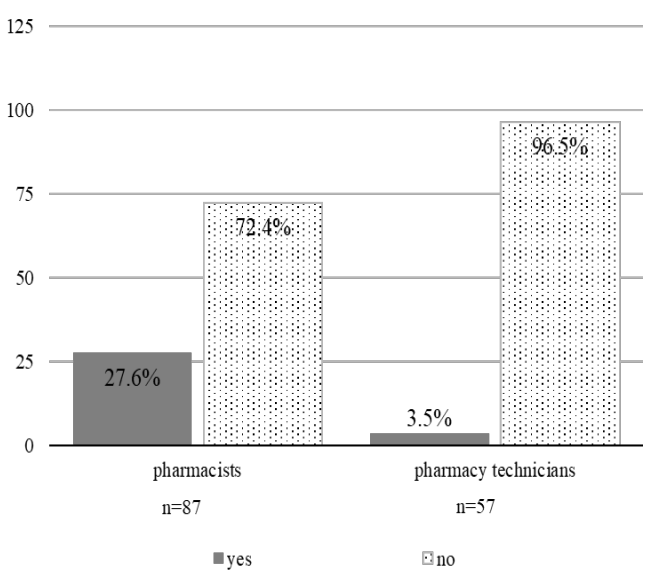

Figure 4.

Patients' preferences towards pharmacy employees consultation in self-treatment $(\mathrm{n}=144 ; \mathrm{p}=0.001)$

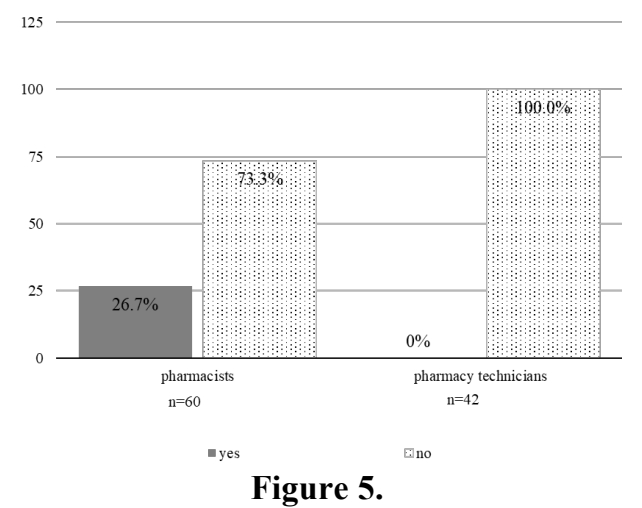

Patients' preferences towards pharmacy employees consultation after physician consultation $(n=102 ; p=$ $0.001)$

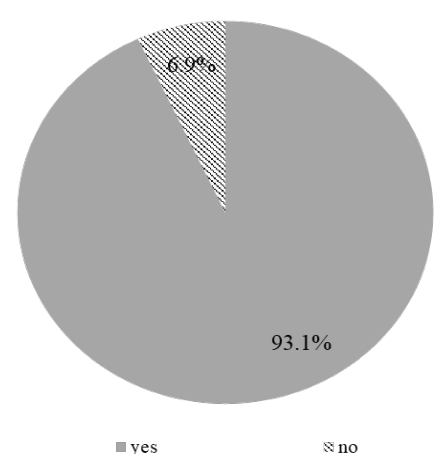

Figure 6.

Pharmacists' evaluation of the correctness of the patients' diagnosis $(n=145 ; \mathrm{p}=0.047)$ 
125

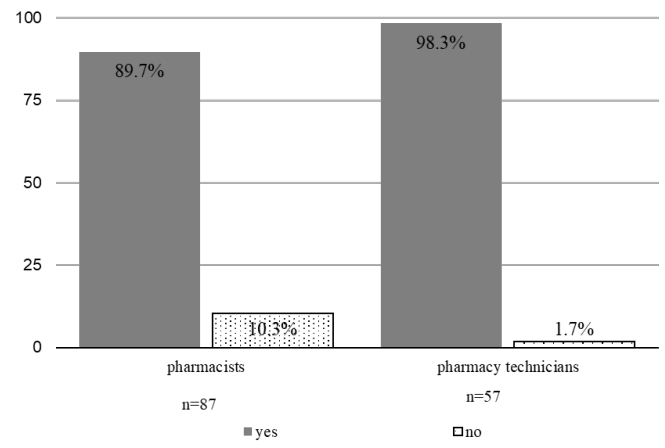

Figure 7.

The effect of the pharmacy employees profession on the correctness of the patients' diagnosis $(n=144$;

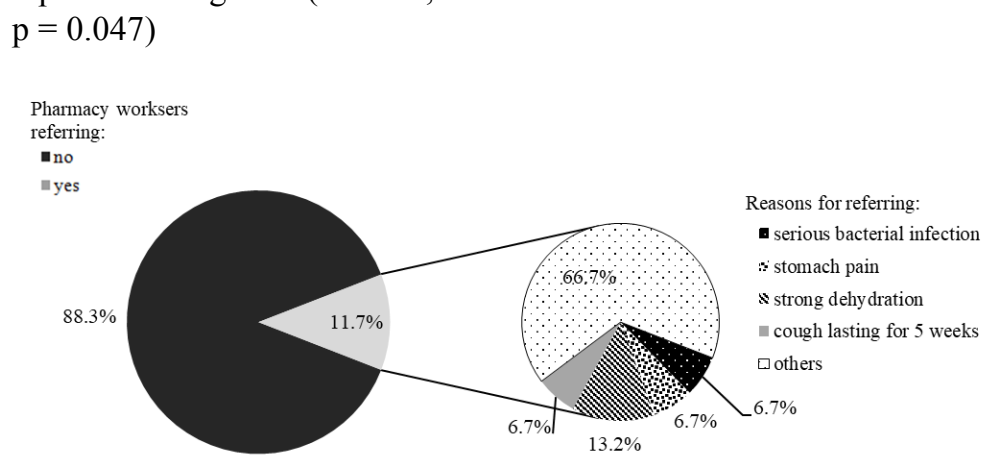

Figure 8.

Reason for patients referring to the physician by pharmacy workers $(n=145)$

125

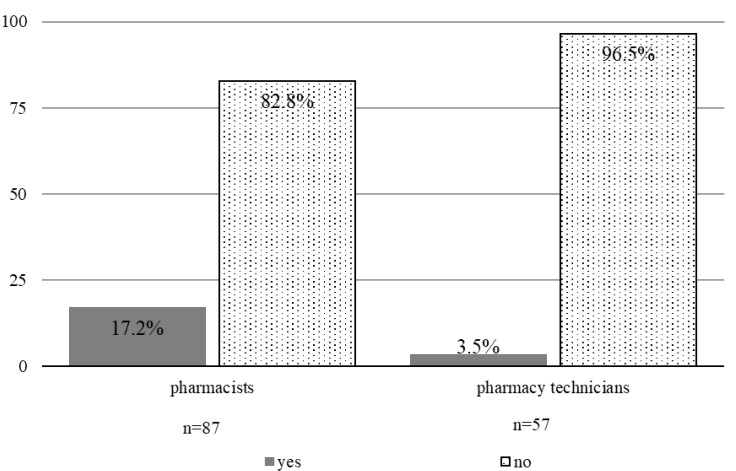

Figure 9.

Referral patients to the physician by pharmacy workers $(n=144 ; p=0.013)$

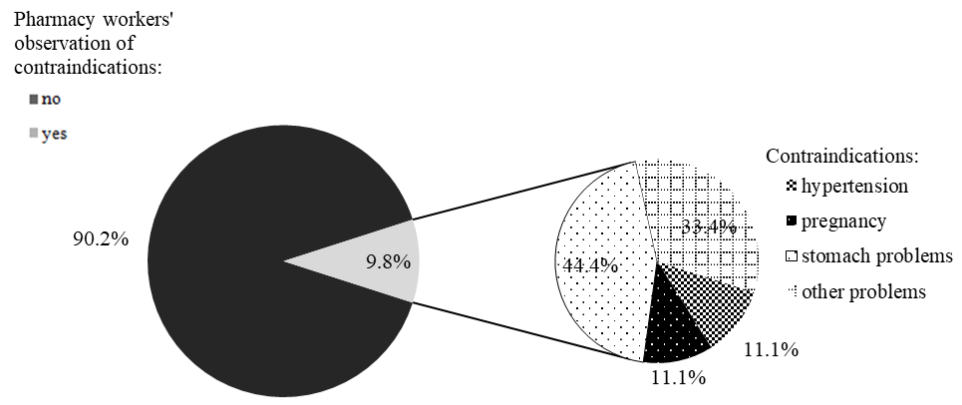

Figure 10.

List of contraindications to medication prescribed by the physician in pharmacy workers opinion $(\mathrm{n}=102)$ 


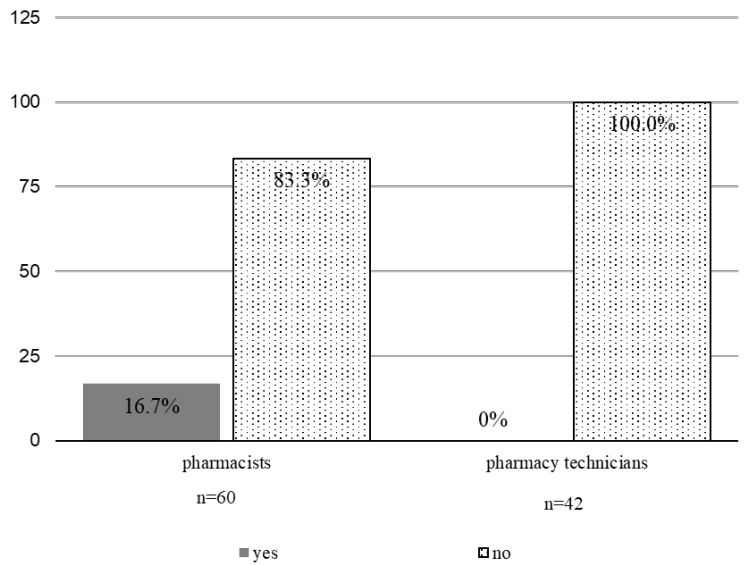

Figure 11.

Contraindications to medication prescribed by the physician in pharmacy workers opinion $(n=102 ; p=0.005)$

The conducted study confirmed that patients report a lot of problems like common cold, pain or allergy in community pharmacy especially towards pharmacists so they can be treated as primary health professionals. People often seek assistance in self-treatment of smaller health issues, such as e.g. skin problems or oral diseases $[3,14]$. That is why community pharmacies are an important part of the health care system and can provide services that may help eliminate excessive consultations by specialists [18].

However surveys conducted among Slovak patients revealed that the most important factors influencing the choice of pharmacy are location and convenient working hours, especially for younger respondents from Bratislava region [7]. These factors probably were also important for the counselled patients in our study. In another publication it was indicated that in patients' opinion pharmacist shouldn't passively wait for their questions and should provide counselling at every stage of therapy [4]. This is why during our study it was pointed out that even when the patient wasn't asking about information concerning the dispensed medicine, she or he should be given a short advice by a pharmacist or technician. Professional pharmacy employees were obligated to select the most appropriate information according to their actual knowledge. In many cases it resulted in extended and detailed consultation because the patient had further questions. It is significant that it happened more often after pharmacists' counselling than pharmaceutical technicians. Patients usually don't ask questions, because they are convinced that their knowledge about medicines is sufficient enough [16]. Nevertheless, pharmacy employees should be able to point out important drug information in order to broaden patients' knowledge and provoke them to be more vigilant with their pharmacotherapy. In our study this aim was achieved mainly by pharmacists. On average, about $1 / 3$ of the patients had further questions after pharmacists' counselling in both cases: self-treatment and after the physician's consultation. This is on contrary to pharmacy technicians' counselling, when only $3.5 \%$ of patients wanted to broaden the consultation by asking questions in self-treatment and none of them was interested in counselling after physician's consultation. According to the Ontario College of Pharmacists, technicians and pharmacists have different roles as health care professionals. Pharmacists should be responsible for the evaluation of therapeutic appropriateness of all prescriptions and for counselling. The role of technicians is to control the technical aspects of prescriptions [9]. In Polish pharmacies that division isn't clear and technicians often have the same duties as pharmacists. Moreover, in the year 2016 there were 13104 community pharmacies in Poland and 26845 pharmacists [6]. Statistically this means there are 2 pharmacists per one pharmacy and it is indisputably not enough in order to be sure that pharmacy technicians are always supervised by a pharmacist.

On the basis of performed analyses it was established that pharmacists are more critical towards patients' self-diagnosis and they more often pointed out contraindications to medications prescribed by physicians. As a result, pharmacists more frequently referred patients to the physician, especially in selftreatment. These conclusions are comparable with other studies conducted in Turkey, which enabled authors to assess pharmacists' and technicians' attitude towards patients with minor illnesses. Pharmacists occurred to be more responsible for patients and were offering more recommendations than technicians [12]. The higher educational level is the reason why pharmacists are more inquisitive and self-confident. In Poland, pharmacists are obligated to complete professional courses as long as they are practicing, which are supposed to acquaint them with the most recent knowledge. Our study shows that pharmacists are more prepared to provide counselling and to watch over the safety of therapy. It is significant that 
pharmacists not only indicated drug problems, such as potential interactions, but also more frequently identified conditions that should be assessed by a specialist. It may be a signal that they are willing to cooperate with physicians and this is one of the most important factors in providing effective PCS and $\mathrm{PC}$ in the future [17].

Other studies conducted in Poland in the period between 2010 and 2012 showed that patients' knowledge increased due to pharmaceutical consultations. Moreover patients indicated in surveys that they expect pharmaceutical counselling that concern dosage, side effects, preparation of medications, purpose of their administration, mechanism of action and drug interactions [1]. Therefore we can assume that pharmacists and pharmacy technicians in our study fulfilled patients' expectations through their counselling. Further studies should be concentrated on patients' satisfaction after visiting a pharmacy and the benefits they can subjectively and objectively get from consulting a pharmacist.

Although the number of respondents was established above the minimum, authors are aware that some comparisons could not achieve the required power to detect smaller differences between groups. Nevertheless, the results have shown some trends in the analysed population.

Answers for questions which considered patients revealed that most of them were young, under 30 years old, which isn't a common patients' structure in community pharmacies. This is probably due to the close neighbourhood of private medical centres in which most of the patients have medical subscription as a non-financial benefit from their employer.

\section{Conclusions}

One of the essential changes in Polish pharmacies, that will allow to implement effective PCS is to reorganize their professional stuff structures and assign competences anew. The authors' scheme of pharmaceutical counselling gives the possibility to cooperate with a patient and physician in a better way, in Poland. Our study showed also that the level of education is an important factor that affects the quality of pharmacy professional employees' counselling.

\section{References}

1. Cerbin-Koczorowska M, Waszyk-Nowaczyk M, Odor K, Michalak M, Piotrowska S, Matschay A, Simon M, Majchrzycki M, Pharmaceutical care as a chance of improving health care in areas with an average level of urbanization. Farmacia, 2017; 65(1): 159-166.

2. Chua SS, Kok LC, Yusof FAM, Tang GH, Lee SWH, Efendie B, Paraidathathu T, Pharmaceutical care issues identified by pharmacists in patients with diabetes, hypertension or hyperlipidaemia in primary care settings. BMC Health Serv Res., 2012; 12(1): 388-348.

3. Dumitrache MA, Ionescu E, Sfeatcu R, Ginghina O, Burcea-Dragomiroiu GTA, Petre A, The pharmacist's role in preventive and pharmaceutical treatment for oral diseases. Farmacia, 2016; 64(6): 966-969.

4. Guillaumie L, Ndayizigiye A, Beaucage C, Moisan J, Grégoire JP, Villeneuve D, Lauzier S, Patient perspectives on the role of community pharmacists for antidepressant treatment: A qualitative study. Can Pharm J. (Ott), 2018; 151(2): 142-148.

5. Horvat N, Kos M, Contribution of Slovenian community pharmacist counselling to patients' knowledge about their prescription medicines: a cross-sectional study. Croat Med J., 2015; 56(1): 41-49.

6. Local Data Bank. Generally available pharmacies and number of pharmacists in Poland in 2016, https://bdl.stat.gov.pl.

7. Minarikowa D, Malovecka I, Foltam V, Patient choice of pharmacy and satisfaction with pharmaceutical care - Slovak regional comparison. Farmacia, 2016; 64(3): 473-480.

8. Morton K, Pattison H, Langley C, Powell R, A qualitative study of English community pharmacists' experiences of providing lifestyle advice to patients with cardiovascular disease. Res Social Adm Pharm., 2015; 11(1): 17-29.

9. Ontario College of Pharmacists, Understanding what a pharmacy technician can do, www.ocpinfo.com.

10. Polish Pharmaceutical Society, Pharmacy development perspectives until 2030, http://oia.krakow.pl.

11. Puspitasari HP, Aslani P, Krass I, Challenges in the care of clients with established cardiovascular disease: Lessons learned from Australian community pharmacists. PLoS ONE, 2014; 9(11): 1-10.

12. Sancar M, Tezcan E, Okuyan B, Izzettin FV, Assessment of the attitude of community pharmacists and pharmacy technicians towards diarrhea: A simulated patient study in Turkey. Trop J Pharm Res., 2015; 14(8): 1509-1515.

13. Skowron A, What's next to the strategy of the drug market?, www.aptekarzpolski.pl, (available in Polish).

14. Tucker R, Stewart D, Why people seek advice from community pharmacies about skin problems. Int $J$ Pharm Pract., 2015; 23(2): 150-153.

15. Waszyk-Nowaczyk M, Błaszczyk K, Michalak M, Frankiewicz A, Bordzio A, Simon M, Pharmaceutical care valuation as a professional and documented service with an influence on pharmaeconomic therapy aspects at old patient. Pol Przegl N Zdr., 2016; 4(49): 386-390.

16. Waszyk-Nowaczyk M, Simon M, Problems with implementation of pharmaceutical care in Poland. Farm Pol., 2009; 65(10): 713-716.

17. Waszyk-Nowaczyk M, Simon M, Szukalska B, Pharmaceutical care as an area of pharmacistphysician collaboration. Nowiny Lekarskie, 2013; 82(3): 262-265.

18. Waszyk-Nowaczyk M, Nowaczyk P, Simon M, Physicians' and patients' valuation of pharmaceutical care implementation in Poznan (Poland) community pharmacies. Saudi Pharm J., 2014; 22(6): 537-544. 